\title{
Pengetahuan dan Sikap Perawat tentang Perawatan Paliatif di Rumah Sakit
}

\author{
Ernawati Siagian $^{1}$, Morri Perangin-angin ${ }^{2}$ \\ Fakultas Ilmu Keperawatan Universitas Advent Indonesia \\ Jl. Kolonel Masturi No.288, Cihanjuang Rahayu, Kec. Parongpong, Kabupaten Bandung Barat, Jawa \\ Barat 40559 \\ Email : ernawatisiagian@unai.edu ${ }^{1}$, mori.peranginangin@unai.edu ${ }^{2}$
}

\begin{abstract}
Abstrak
Pendahuluan : Perawatan paliatif dibutuhkan oleh pasien dengan penyakit terminal, di mana pelayanan kuratif tidak dimungkinkan lagi bagi pasien. Namun belum semua rumah sakit di Indonesia memiliki fasilitas perawatan paliatif serta kurangnya pengetahuan perawat mengenai paliatif.
\end{abstract}

Tujuan : Tujuan dari penelitian ini adalah mengetahui tingkat pengetahuan dan sikap perawat terhadap perawatan paliatif, serta mencari tahu apakah terdapat hubungan antara tingkat pengetahuan dan sikap perawat terhadap perawatan paliatif.

Metode : Metode yang digunakan dalam penelitian ini adalah deskriptif korelasi dengan menggunakan tehnik sampel convinience yang berjumlah 120 responden yang bekerja di rumah sakit swasta di Bandar Lampung.Untuk mengukur tingkat pengetahuan digunakan kuesioner The Palliative Care Quiz for Nursing (PCQN), sedangkan untuk mengukur sikap digunakan kuesioner Frommelt's Attitude Toward Care of the Dying (FATCOD) scale.

Hasil : Hasil menunjukan bahwa tingkat pengetahuan perawat terhadap perawatan paliatif dalam kategori rendah $(99,17 \%)$, sedangkan sikap perawat terhadap perawatan paliatif dalam kategori sedang (70,83\%). Hasil uji Spearman rho menunjukkan bahwa ada hubungan yang signifikan antara pengetahuan dan sikap perawat dengan nilai $\mathrm{p}$ value $0,011<0,05$. Tingkat pengetahuan perawat dalam kategori rendah dan sikap perawat dalam kategori sedang. Nilai korelasi yang didapatkan $r=$ 0,230 berarti ada hubungan yang searah dengan tingkat keeratan yang sangat lemah.

Kesimpulan : Peningkatan pengetahuan tentang perawatan paliatif sangat penting untuk mengkaji masalah dan kebutuhan pasien dalam upaya meningkatkan kualitas hidup pasien.diharapkan dengan meningkatnya pengetahuan akan berpengaruh terhadap sikap perawat dalam pelayanan paliatif.

Kata kunci : perawatan paliatif, pengetahuan, sikap

\begin{abstract}
Introduction : Palliative care is needed by patients with a terminal illness, where curative care is no longer possible for patients.

However, not all hospitals in Indonesia have palliative care facilities and there is a lack of nurses' knowledge about palliative.
\end{abstract}

Objective : The purpose of this study is to determine the level of knowledge and attitudes of nurses towards palliative care, and find out whether there is a relationship between the level of knowledge and attitudes of nurses towards palliative care.

Method : The method used in this study is a descriptive correlation by using a sample convenience technique of 120 respondents working in the non-government hospital in Bandar Lampung. The Palliative Care Quiz for Nursing (PCQN) questionnaire was used to measure the level of knowledge, while the Frommelt's Attitude Toward Care of the Dying (FATCOD) scale was used to measure the attitudes.

Result : The results showed that the level of nurses' knowledge of palliative care was in a low category $(99,17 \%)$, while the nurses' attitude towards palliative care was in the moderate category (70,83\%). The Spearman rho test results showed that there is a significant relationship between nurses' knowledge and attitudes with a p-value of 0.011 $<0.05$. The level of knowledge of nurses is in a low category and nurses' attitudes are in the moderate category. Correlation value obtained $r=0.230$ means there is a direct relationship with a very weak level of closeness. Conclusion : Increased knowledge about palliative care is very important to assess the patient's problems and needs in an effort to improve the quality of life of patients. It is hoped that increased knowledge will affect nurses' attitudes in palliative care.

Keywords : Palliative care, knowledges, attitudes 


\section{Pendahuluan}

Perawatan paliatif merupakan salah satu jenis perawatan yang diberikan secara total baik kepada pasien maupun keluarga pasien yang menderita penyakit yang mengancam jiwa yang diberikan oleh tim secara interdisiplin dimana penyakit yang diderita pasien tidak memberikan respon terhadap perawatan yang diberikan dan tidak dapat memperpanjang usia hidup pasien.

Menurut World Health Organization, beberapa penyakit kronis seperti penyakit kardiovaskular, kanker, penyakit pernapasan kronis, HIV/AIDS, diabetes mellitus, gagal ginjal, penyakit hati kronis, multiple sclerosis, penyakit Parkinson, rheumatoid arthritis, penyakit neurologis, demensia, anomaly congenital, dan tuberculosis yang resistan telah mengalami peningkatan jumlah penderita. ${ }^{1}$ Prinsip pelayanan paliatif: 1) menghilangkan nyeri dan gejala fisik lain, 2) menghargai kehidupan dan menganggap kematian sebagai proses normal, 3) tidak bertujuan mempercepat atau menunda kematian, 4) mengintegrasikan aspek psikologis, social dan spiritual, 5) memberikan dukungan agar pasien dapat hidup seaktif mungkin, 6) memberikan dukungan kepada keluarga sampai masa dukacita, 7) menggunakaan pendekatan tim untuk mengatasi kebutuhan pasien dan keluarganya, 8) menghindari tindakan sia-sia. ${ }^{2}$

Berdasarkan prevalensi WHO pada tahun 2011 dari 29 miliar kasus penyakit paliatif yang ada, sekitar 20,4 miliar kasus membutuhkan perawatan paliatif. Bahkan di Indonesia, tingkat kematian pada tahun 2011 mencapai angka 1.064.000. Jumlah pasien yang menderita penyakit yang belum dapat disembuhkan terus meningkat setiap tahunnya. ${ }^{3}$ Di Indonesia sendiri perawatan paliatif jarang ditemui karena masih berada pada tahap perkembangan awal dan hanya sebatas pada tempat tertentu seperti pada beberapa rumah sakit yang menyediakan pelayanan perawatan paliatif di daerah tertentu. Berdasarkan penelitian yang dilakukan oleh Indarwati (2019) didapati bahwa adanya keterbatasan pada perawat yang memiliki keterbatasan pengetahuan mengenai perawatan paliatif dan komunikasi yang tidak efektif dalam perawatan paliatif dan keterbatasan sumber daya yang lain. ${ }^{4}$
Penyelenggaraan perawatan paliatif di Indonesia masih dalam masa pertumbuhan dan masih terbatas pada rumah sakit tertentu. Jumlah tenaga kesehatan yang paham akan konsep pelayanan paliatif pun masih terbatas. Alhasil, lebih banyak pasien meninggal di rumah sakit tanpa menerima perawatan paliatif tertentu atau mereka meninggal di rumah tanpa dukungan yang memadai dari para professional perawatan paliatif. Pasien juga mengalami berbagai penderitaan terkait dengan gejala penyakit yang mestinya tidak perlu terjadi jika kebutuhan mereka akan pelayanan paliatif terpenuhi dengan baik. Perawat memiliki peran yang sangat besar dalam perawatan paliatif oleh karena perawat memiliki waktu yang lebih lama bersama pasien dibandingkan dengan pemberi asuhan lainnya sehingga perawat lebih mengetahui perkembangan keadaan pasien yang terbaru. ${ }^{5}$ Namun perawat memiliki pengetahuan yang terbatas mengenai perawatan paliatif sehingga mengakibatkan kurang maksimalnya pemberian perawatan paliatif pada pasien.

Perawatan paliatif sangat dibutuhkan oleh pasien yang menderita penyakit yang sulit untuk disembuhkan, bahkan dalam keadaan yang mengancam nyawa sekalipun. Perawatan paliatif harus bisa diintergrasikan ke semua fasilitas pelayanan kesehatan yang ada dan lebih efektif jika ada tempat pelayanan yang khusus untuk perawatan paliatif. Hal ini tentunya menuntut pengetahuan yang baik tentang perawatan paliatif khususnya bagi perawat.

Rumah sakit yang menjadi lokasi penelitian ini merupakan salah satu rumah sakit swasta di Bandar Lampung. Penelitian ini bertujuan untuk mengetahui tingkat pengetahuan dan sikap perawat terhadap perawatan paliatif. Sehingga diharapkan perawat lebih berfokus pada dukungan dan motivasi ke penderita, kemudian setiap keluhan yang timbul ditangani dengan pemberian obat untuk mengurangi rasa sakit, perawatan paliatif dapat mengeksplorasi individu penderita dan keluarganya bagaimana memberikan perhatian khusus terhadap penderita, penanggulangannya serta kesiapan untuk menghadapi kematian. 


\section{Metode}

Penelitian ini merupakan penelitian deskriptif korelasi yang dilakukan kepada 120 orang perawat. Pengambilan sampel dilakukan dengan caraconvenience. Pengumpulan data dilakukan pada bulan Februari 2020 setelah mendapat persetujuan dari bagian Komite Etik Penelitian Kesehatan Research Ethics Committee Universitas Advent Indonesia No. 047/KEPK-FIK.UNAI/EC/II/20 dan Surat ijin penelitian dari Direktur Rumah Sakit Advent Bandar Lampung sebagai tempat penelitian dilakukan. Analisa univariat dilakukan untuk menentukan frekuensi dan persentase dari masing-masing vairabel.Setelah melakukan uji normalitas dengan Kolmogorov-Smirnov dan hasilnya data tidak terdistribusi normal, maka analisa bivariate dilakukan dengan Spearmanrho untuk melihat apakah terdapat hubungan antara pengetahuan dan sikap perawat terhadap perawatan paliatif. Instrumen yang digunakana adalah kuesioner PCQN (Palliative Care Quiz for Nursing). Tingkat pengetahuan perawat akan dikelompokkan dalam tiga kategori, yaitu $<56 \%=$ rendah, $56 \%-75 \%=$ cukup, dan $76 \%$ $-100 \%=$ tinggi.

Sedangkan untuk mengukur Sikap perawat digunakan kuesioner Frommelt's Attitude Toward Care of the Dying (FATCOD) Scale menggunakan 5 skala Likert yaitu sangat tidak setuju, tidak setuju, ragu ragu, setuju, sangat setuju. Untuk pernyataan positif jawaban sangat tidak setuju diberi skor 1 dan sangat setuju diberi skor 5.Sebaliknya untuk pernyataan negatif jawaban sangat tidak setuju diberi skor 5 dan sangat setuju diberi skor 1.Nilai sikap responden diinterpretasikan menjadi $\angle 56 \%=$ buruk, $56 \%-75 \%=$ sedang, $76-100=$ baik.

\section{Hasil}

Distribusi data responden berdasarkan jenis kelamin, tingkat pendidikan, lama masa kerja, unit kerja serta pelatihan perawatan paliatif dapat dilihat pada tabel 1 .

Tabel 1. Distribusi Karakteristik Responden (N=120)

\begin{tabular}{|c|c|c|c|}
\hline Variabel & Kategori & Frekuensi & Persentase \\
\hline \multirow[t]{2}{*}{ Jenis Kelamin } & Laki-laki & 27 & $22,5 \%$ \\
\hline & Perempuan & 93 & $77,5 \%$ \\
\hline \multirow[t]{3}{*}{ Tingkat Pendidikan } & D3 & 42 & $35 \%$ \\
\hline & S1 & 74 & $61,7 \%$ \\
\hline & S2 & 4 & $3,33 \%$ \\
\hline \multirow[t]{4}{*}{ Lama Bekerja } & $1-5$ tahun & 40 & $33,3 \%$ \\
\hline & $6-10$ tahun & 24 & $20 \%$ \\
\hline & $11-15$ tahun & 24 & $20 \%$ \\
\hline & $>15$ tahun & 32 & $26,7 \%$ \\
\hline \multirow[t]{2}{*}{ Unit kerja } & Unit Medikal Bedah & 79 & $65,8 \%$ \\
\hline & Unit Kritis & 41 & $34,2 \%$ \\
\hline \multirow[t]{2}{*}{ Pelatihan } & Pernah Pelatihan & 6 & $5 \%$ \\
\hline & Belum Pernah & 114 & $95 \%$ \\
\hline
\end{tabular}
tingkat pendidikan S1 $(61,7 \%)$, dan masa

Tabel 2. Persentase Pengetahuan dan Sikap Responden Terhadap Perawatan Paliatif

\begin{tabular}{llll}
\hline & Kategori & Frekuensi & Persentase \\
\cline { 2 - 4 } Pengetahuan Perawat & Rendah & 119 & $99,17 \%$ \\
& Cukup & 1 & $0,83 \%$ \\
& Tinggi & 0 & $0 \%$ \\
Sikap Perawat & Total & 120 & $100 \%$ \\
\hline 127 & Buruk & 0 & $0 \%$ \\
& Submited:28/06/20 & Accepted: $12 / 09 / 20$ \\
& Review: $23 / 07 / 20$ & Published:30/09/20
\end{tabular}




\begin{tabular}{lll}
\hline Sedang & 85 & $70,83 \%$ \\
Baik & 35 & $29,17 \%$ \\
Total & 120 & $100 \%$ \\
\hline
\end{tabular}

Tabel 2 menunjukan bahwa 99,17 $\%$ responden mempunyai tingkat pengetahuan yang rendah, $0,83 \%$ yang memiliki pengetahuan yang cukup tentang perawatan paliatif. Tabel 2 juga menunjukkan $70,83 \%$ perawat mempunyai sikap sedang terhadap perawatan paliatif, $29,17 \%$ perawat yang mempunyai sikap baik terhadap perawatan paliatif.

Tabel 3. Hubungan Pengetahuan dan Sikap Terhadap Perawatan Paliatif

\begin{tabular}{llllll}
\hline & Variabel & Mean & StandarDeviasi & Sig & Correlation Coeficient \\
\cline { 2 - 6 } $\begin{array}{l}\text { Spearman } \\
\text { rho }\end{array}$ & Pengetahuan & 7.53 & 2.082 & .011 & .230 \\
& Sikap & 107.43 & 10.993 & & \\
\hline
\end{tabular}

Tabel 3 menunjukan bahwa ada
hubungan yang signifikan antara tingkat pengetahuan dan sikap perawat terhadap perawatan paliatif dengan nilai sig $0,011<0.05$. Nilai correlation coefficient 0,230 menunjukkan tanda positif yang berarti bahwa pengetahuan dan sikap perawat tentang perawatan paliatif memiliki hubungan yang searah dengan tingkat keeratan hubungan yang sangat lemah.
Tabel 4 menunjukan bahwa jenis kelamin, tingkat pendidikan, lama kerja, unit kerja dan pelatihan paliatif tidak ada hubungan yang signifikan dengan tingkat pengetahuan perawat tentang perawatan paliatif( $\operatorname{sig}>0,05)$. Namun hubungan antara jenis kelamin dan unit kerja terhadap pengetahuan memiliki tanda negatif yang berarti bahwa jenis kelamin dan unit kerja memiliki hubungan yang berlawanan arah dengan tingkat pengetahuan perawat tentang perawatan paliatif.

Tabel 4. Hubungan Masing-Masing Variabel Dengan Tingkat Pengetahuandan Sikap

\begin{tabular}{lllllll}
\hline & Variabel & \multicolumn{3}{l}{ Sengetahuan } & \multicolumn{2}{l}{ Sikap } \\
\cline { 3 - 6 } & & $\begin{array}{l}\text { Correlation } \\
\text { Coefficient }\end{array}$ & $\begin{array}{l}\text { Sig } \\
\text { tailed })\end{array}$ & $\begin{array}{l}\text { (2- } \\
\text { Correlation } \\
\text { Coefficient }\end{array}$ & $\begin{array}{l}\text { Sig (2- } \\
\text { tailed) }\end{array}$ \\
& Jenis Kelamin & -.157 & .086 & -.112 & .223 \\
& Tingkat Pendidikan & .085 & .356 & .340 & .000 \\
& Lama kerja & .033 & .724 & .149 & .103 \\
& Unit Kerja & -.092 & .316 & -.029 & .752 \\
& Pelatihan Paliatif & .054 & .557 & -.065 & .483 \\
\hline
\end{tabular}


Selain itu tabel di atas juga menunjukkan bahwa jenis kelamin, lama kerja, unit kerja dan pelatihan paliatif tidak ada hubungan yang signifikan dengan sikap perawat terhadap perawatan paliatif (sig > 0,05). Namun sebaliknya tingkat pendidikan memiliki hubungan yang sginifikan dengan sikap perawat terhadap perawatan paliatif. Hubungan antara jenis kelamin, unit kerja, dan pelatihan paliatif memiliki tanda negatif yang berarti bahwa jenis kelamin, unit kerja dan pelatihan paliatif memiliki hubungan yang berlawan arah dengan sikap perawat.

\section{Pembahasan}

Hasil penelitian menunjukan bahwa 99,17 \% responden mempunyai tingkat pengetahuan yang rendah, $70,83 \%$ perawat mempunyai sikap sedang terhadap perawatan paliatif, 29,17 \% mempunyai sikap baik terhadap perawatan paliatif. Hal ini sesuai dengan penelitian yang dilakukan oleh Indarwati (2019) bahwa perawat memiliki keterbatasan mengenai pengetahuan tentang perawatan paliatif sehingga pemberian pelayanan perawatan paliatif menjadi kurang maksimal. Hal ini didukung dengan hasil penelitian dari Ilham (2019) yang menyatakan bahwa ada hubungan antara pengetahuan dan sikap perawat. Semakin baik pengetahuan yang dimiliki oleh seorang perawat, maka semakin baik pula sikap seorang perawat dalam memberikan perawatan paliatif terhadap pasien yang dirawatnya. ${ }^{7}$ Demikian juga dengan hasil penelitian yang dilakukan oleh Wulandari (2012) yang menyatakan bahwa semakin tinggi tingkat pengetahuan perawat maka sikap yang diberikan oleh seorang perawat dalam melakukan perawatan paliatif akan semakin baik. ${ }^{8}$ Hal ini berarti bahwa pengetahuan yang dimiliki oleh perawat memiliki pengaruh yang memberikan hubungan yang positif terhadap sikap yang akan dilakukan dalam melaksanakan perawatan paliatif. Selain itu, perawat perlu ditanamkan sifat caring sejak awal khususnya ketika dalam masa perkuliahan sebagai inti dari keperawatan itu sendiri. Seorang perawat wajib memberikan perlakuan yang baik dan memberikan dukungan kepada pasien dan keluarganya 129

Submited:28/06/20

Review: 23/07/20 sebagai tanda seorang perawat memiliki sikap yang baik.

Hasil dari penelitian menyatakan bahwa jenis kelamin, tingkat pendidikan, lama kerja, unit kerja dan pelatihan paliatif tidak ada hubungan yang signifikan dengan tingkat pengetahuan perawat tentang perawatan paliatif( sig> 0,05). Namun hubungan antara jenis kelamin dan unit kerja terhadap pengetahuan memiliki tanda negatif yang berarti bahwa jenis kelamin dan unit kerja memiliki hubungan yang berlawanan arah dengan tingkat pengetahuan perawat tentang perawatan paliatif. Menunjukkan bahwa jenis kelamin, lama kerja, unit kerja dan pelatihan paliatif tidak ada hubungan yang signifikan dengan sikap perawat terhadap perawatan paliatif (sig > 0,05). Namun sebaliknya tingkat pendidikan memiliki hubungan yang sginifikan dengan sikap perawat terhadap perawatan paliatif. Hubungan antara jenis kelamin, unit kerja, dan pelatihan paliatif memiliki tanda negatif yang berarti bahwa jenis kelamin, unit kerja dan pelatihan paliatif memiliki hubungan yang berlawan arah dengan sikap perawat. Penelitian yang dilakukan oleh Agnes Trigiarti (2018), pengetahuan dapat dipengaruhi oleh lama kerja dan pengalaman. ${ }^{9}$ Lama bekerja seseorang akan menentukan banyak pengalaman yang dipatkannya. Tingkat kematangan dalam berpikir dan berperilaku dipengaruhi oleh pengalaman kehidupan sehari-hari. ${ }^{10}$ Hal ini menunjukkan bahwa semakin lama masa kerja akan semakin tinggi tingkat kematangan seseorang dalam berpikir sehingga lebih meningkatkan pengetahuan yang dimiliki. Notoadmodjo mengatakan bahwa ada beberapa faktor yang mempengaruhi tingkat pengetahuan, salah satunya yaitu tingkat pendidikan. ${ }^{11}$ Tingkat pendidikan yang tinggi dapat membuat tingkat pengetahuan seseorang tinggi. Latar belakang seorang perawat menentukan tingkat pengetahuan seseorang, termasuk latar belakang pendidikan. ${ }^{12}$ Henry (2010) dalam penelitiannya juga menemukan bahwa ada hubungan tingkat pengetahuan perawat dengan lama pengalaman kerja. ${ }^{13}$ Seorang perawat yang sudah lama bekerja akan memiliki 
pengalaman yang lebih banyak, khususnya pengalaman saat rotasi kerja. Jenis kelamin tidak memiliki hubungan yang erat dengan tingkat pengetahuan. Hal ini disebabkan karena laki-laki dan perempuan memiliki kesempatan yang sama dan memiliki sumber pengetahuan dan informasi yang berbeda-beda sehingga memungkinkan semua orang untuk medapat informasi yang sama dengan cara yang berbeda. ${ }^{14}$ Pelatihan perawatan paliatif dapat menambah pengetahuan dan wawasan tentang perawatan paliatif. ${ }^{15}$ Choi, Jung dan Kim (2011) juga menyatakan hal yang serupa bahwa pelatihan dan pendidikan paliatif akan meningkatkan pengetahuan perawat mengenai hospis dan perawatan paliatif. ${ }^{16}$

Hasil penelitian menunjukan bahwa ada hubungan yang signifikan antara tingkat pengetahuan dan sikap perawat terhadap perawatan paliatif dengan nilai sig $0,011<0.05$.

Hal ini sejalan dengan penelitian oleh Yuke Kiran (2017), bahwa terbentuknya sikap positif dari perawat dapat dipengaruhi oleh interaksi antar sesama perawat, karena sikap terbentuk dengan interaksi terjadi saling tukar informasi mengenai hal yang berhubungan dengan pelaksanaan asuhan keperawatan, perawat mau memperhatikan kebutuhan klien, mengerjakan dan menyelesaikan yang diberikan serta mengajak orang lain untuk mengerjakan atau mendiskusikan suatu masalah. ${ }^{17}$ Sikap perawat kurang baik disebabkan karena tidak adanya program pelatihan perawatan paliatif. Penelitian oleh Ayed (2015) menunjukkan bahwa 6,2\% responden mempunyai sikap yang mendukung terhadap perawatan paliatif. Sikap terhadap perawatan paliatif dipengaruhi oleh kualifikasi pendidikan, pengalaman, dan pelatihan tentang perawatan paliatif yang diterima oleh perawat. ${ }^{18}$ Sikap memiliki berbagai tingkatan, yang pertama menerima (receiving), kedua merespon (responding), ketiga menghargai (valuing) dan terakhir bertanggung jawab (responsible) yaitu bertanggung jawab atas segala yang dipilihnya dengan segala resiko yang mungkin akan terjadi. Adapun faktor lain yang dapat mempengaruhi sikap adalah pengalaman. $^{19}$ Pengetahuan memegang peranan penting dalam penentuan sikap yang utuh (total attitude). Sikap dapat diubah dengan cara meningkatkan pengetahuan. Sikap negatif cenderung menurun sebagai akibat dari meningkatnya tingkat pengetahuan. ${ }^{11}$ Semakin tinggi tingkat pengetahuan perawat tentang perawatan paliatif, semakin baik pula sikap perawat terhadap penatalaksanaan pasien dalam perawatan paliatif. Tingkat pengetahuan dan sikap perawat yang baik dapat diperoleh dari pengalaman, dan pelatihan. Semakin lama perawat bekerja, semakin meningkat pula pengalamannya bekerja diberbagai macam ruangan melalui program rotasi kerja. $^{8}$ Rotasi kerja memperluas pengalaman dan kemampuan perawat, dengan pengalaman tersebut akan meningkatkan kemampuan baik pengetahuan (Knowledge) maupun keterampilan (skill).

\section{Kesimpulan}

Hasil penelitian ini menunjukkan bahwa walaupun pengetahuan perawat masih rendah namun sikap yang ditunjukkan dalam kategori sedang. Serta menunjukkan bahwa ada hubungan yang signifikan antara tingkat pengetahuan dan sikap perawat terhadap perawatan paliatif. Perawatan paliatif merupakan bentuk pelayanan yang bertujuan memperbaiki kualitas hidup pasien dan keluarga dari penyakit yang dapat mengancam jiwa, dengan pengetahuan yang baik di harapkan sikap perawat dalam memberikan perawatan paliatif kepada pasien dan keluarga menjadi lebih baik.

\section{Daftar Pustaka}

1. WHO. Definition of Palliative Care. (2018).

2. Kementerian Kesehatan RI. Pedoman Teknis Pelayanan Paliatif Kanker. (2013).

3. Kementerian Kesehatan RI. Kebijakkan Perawatan Paliatif. Pusat Data dan Informasi (2017).

4. Indarwati, R. et al. Palliative and end-oflife care's barriers for older adults. Work. with Older People (2019) doi:10.1108/WWOP-08-2019-0021. 
5. Adhisty, K. Pelayanan Paliatif Pada Pasien Kanker di RSUP Dr. Sardjito Yogyakarta. J. Fak. Keperawatan Univ. Gadjah Mada Yogyakarta (2015).

6. Campbell, M. L. Nurse to Nurse Palliative Care. Journal of Chemical Information and Modeling (2013). doi:10.1017/CBO9781107415324.004.

7. Ilham, R., Mohammad, S. \& Yusuf, M. N. S. Hubungan Tingkat Pengetahuan Dengan Sikap Perawat Tentang Perawatan Paliatif. Jambura Nurs. J. (2019) doi:10.37311/jnj.v1i2.2515.

8. Wulandari, F. Hubungan Tingkat Pengetahuan Perawat tentang Perawatan Paliatif dengan Sikap terhadap Penatalaksanaan Pasien dalam Perawatan Paliatif di RS Dr. Moewardi Surakarta. (2012).

9. Giatri, A. T. Gambaran Pengetahuan Perawat Tentang Perawatan Paliatif Pada Pasien Kanker Di RSUD DR. MOEWARDI. (2018).

10. Sunaryo. Psikologi untuk pendidikan. ECG (2010).

11. S. Notoadmodjo. Pendidikan dan perilaku kesehatan. Metodologi Penelitian Kesehatan (PT. Rineka Jaya, 2012).

12. Hou, S. Y. \& Lee, R. P. Nurses' knowledge, attitudes and behavior intentions in the care of terminal stage cancer patients with Dyspnea. J. Nurs. (2009) doi:10.6224/JN.56.3.46.
13. Henry, M. D. Knowledges and Attitudes of Nurses About Pain Management In Patients with Cancer. (Ball State University, 2010).

14. Wahyuni, S. Hubungan Antara Pengetahuan Remaja tentang Penyakit Menular Seksual (PMS) dengan Jenis Kelamin dan Sumber Informasi di SMAN 3 Banda Aceh. J. Ilm. STIKES U'Budiyah 1, (2012)

15. Andriaansen \& M, M. J. Effects of A Postqualification Course In Palliative Care. J. Adv. Nurs. (2005).

16. Choi, S., Jung, Y. \& Kim, B. The Effects of An End-Of-Life Nursing Education Consortium Course on Nurses. J. Hosp. Palliat. Nurs. 13, (2011).

17. Kiran, Y. \& Dewi, U. S. P. Pengetahuan dan sikap Perawat dalam memenuhi kebutuhan psikologis dan spiritual klien terminal. J. Pendidik. KEPERAWATAN Indones. doi:10.17509/jpki.v3i2.9425.

18. Ayed, A., Sayej, S., Harazneh, L., Fashafsheh, I. \& Eqtait, F. The Nurses' Knowledge and Attitudes towards the Palliative Care. J. Educ. Pract. 6, (2015).

19. Wawan, A. \& Dewi, M. Teori \& Pengukuran. Pengetahuan, Sikap, Dan Perilaku Manusia. Yogyakarta Nuha Med. (2011) doi:10.1073/pnas.0503726102. 
